\title{
Development and characterisation of protein films derived from dried distillers' grains with solubles and in-process samples
}

Article

Accepted Version

Creative Commons: Attribution-Noncommercial-No Derivative Works 4.0

Prabhakumari, P., Chatzifragkou, A., Kosik, O., Lovegrove, A., Shewry, P. R. and Charalampopoulos, D. (2018) Development and characterisation of protein films derived from dried distillers' grains with solubles and in-process samples. Industrial Crops and Products, 121. pp. 258-266. ISSN 09266690 doi: https://doi.org/10.1016/j.indcrop.2018.05.016 Available at https://centaur.reading.ac.uk/77039/

It is advisable to refer to the publisher's version if you intend to cite from the work. See Guidance on citing.

Published version at: https://doi.org/10.1016/j.indcrop.2018.05.016

To link to this article DOI: http://dx.doi.org/10.1016/j.indcrop.2018.05.016

Publisher: Elsevier

All outputs in CentAUR are protected by Intellectual Property Rights law, including copyright law. Copyright and IPR is retained by the creators or other copyright holders. Terms and conditions for use of this material are defined in the End User Agreement. 


\section{www.reading.ac.uk/centaur}

\section{CentAUR}

Central Archive at the University of Reading

Reading's research outputs online 
Development and characterisation of protein films derived from dried distillers' grains with solubles and in-process samples

Parvathy Prabhakumari $^{\mathrm{a}}$, Afroditi Chatzifragkou ${ }^{\mathrm{a}}$, Ondrej Kosik ${ }^{\mathrm{b}}$, Alison Lovegrove ${ }^{\mathrm{b}}$, Peter R. Shewry ${ }^{\mathrm{b}}$ and Dimitris Charalampopoulos ${ }^{\mathrm{a} *}$

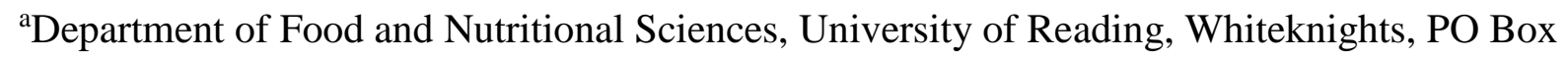
226, Reading RG6 6AP, UK

bepartment of Plant Science, Rothamsted Research, Harpenden, AL5 2JQ, Hertfordshire, UK

*Corresponding author: d.charalampopoulos@ reading.ac.uk 


\begin{abstract}
Polymer films were developed utilising proteins extracted from wheat distillers' dried grains with solubles (DDGS) and in-process samples (wet solids), both by-products of bioethanol production process. Structural characterisation of DDGS and wet solids films indicated a change in the secondary structure of the proteins, reflecting the impact of DDGS production process such as effect of enzyme on protein properties and consequently on the film properties; whereas the developed films exhibited a rough surface with voids. Determination of moisture sensitivity indicated that DDGS films exhibited more hydrophilicity than wet solids films, with the same trend being observed for their water solubility and water uptake. The moisture content and solubility of DDGS films ranged from 10.2-14.2 \% and 32.3-41.8 \% respectively whereas those for wet solids' film ranged from 18.9-19.8 \% and 23.8-24.2\% respectively. The mechanical properties of DDGS and wet solids (ranging from 0.27-0.32 $\mathrm{MPa}$ ) were comparatively lower than commercial wheat gluten film (0.6 MPa). The poor mechanical properties and high water vapour permeability of DDGS and the wet solids films limit their application as biodegradable packaging materials. However, based on their hydrophilicity, the developed films have potential applications in agriculture and horticulture as controlled release matrices and soil conditioners.
\end{abstract}

Keywords: Distillers' dried grains with solubles, FTIR, film properties, thermogravimetric analysis, gluten, bioethanol 


\section{Introduction}

Distillers' dried grains with solubles (DDGS) is a by-product of bioethanol and distillery industries, which is produced in large quantities annually worldwide (Hu et al. 2011). Distillers grains typically comprise proteins (27-33\%), hemicellulose (20\%), cellulose (15\%), crude lipids (10\%), as well as trace amounts of starch and lignin (Xiang et al. 2014). The production of DDGS has been increasing significantly during the past decade due to the growth of the biofuel industry. According to the Organization of Economic Corporation and Development, the growth rate in the production of ethanol is projected to be 19 billion litres in the next ten years (OECD 2017). Based on these projections, such increased growth of the bioethanol industry is expected to have a direct influence on the production and availability of DDGS. It is estimated that the total production of bioethanol derived DDGS in U.S and Europe would be 44 and 9 million tonnes respectively by 2018 (OECD 2009).

Currently, DDGS is regarded as a low-value by-product that is mainly used as a protein-rich animal feed (Muniyasamy et al. 2013). However, studies have shown that the compositional variability of DDGS can affect its nutritional quality and digestibility and may result in health problems in animals (Wu and Munkvold, 2008). This often limits the application of DDGS as an animal feed. However, this heterogeneous by-product can also be utilised as starting material for the development of added-value products that may open new income streams for bioethanol producers and distillers.

One of the first studies in this regard was the valorisation of DDGS by incorporating it with polyolefine polymers such as polypropylene (PP) and polyethylene (PE) (Julson et al. 2004). There are reports on the development of composites from DDGS by chemical modification and blending with other polymers (Li and Sun, 2011; Tatara et al. 2009). The possible applications of DDGS as a bio-filler along with other polymers and resins for the synthesis of biocomposites have also been studied (Hu et al. 2011; Tatara et al. 2009). 
Although Julson et al. (2004) concluded that DDGS cannot be accepted as a bio-filler since the thermoplastics incorporated with DDGS lacked of mechanical strength, further research showed that DDGS can be used as a bio-filler with phenolic resin to increase the biodegradability of the resulting composite (Tatara et al. 2009). Biocomposites of DDGS/polylactic acid (PLA) prepared by thermal compounding were also shown to exhibit mechanical properties similar to that of pure PLA (Li and Sun, 2011). In another study, DDGS was modified by green surface treatment and used with polyhydroxy (butyrate-covalarate) for the preparation of bioplastics (Zarrinbakhsh et al. 2011).

Corn (maize) DDGS has been used for the preparation of thermoplastic films that possessed satisfactory mechanical properties (Hu et al. 2011), while Reddy et al. (2014) grafted methacrylates on to sorghum-DDGS to produce films with low water stability. Cellulose extracted from DDGS has also been used to prepare films to be used as water absorbents (Xu et al. 2009) while an alkali-soluble hemicellulose-rich biopolymer fraction from DDGS was made into stand-alone films (Xiang et al. 2014). However, there are few reports on the development of films from proteins extracted from wheat DDGS.

The major protein component of wheat DDGS, is gluten, which is well-characterised because its visco-elastic properties underpin the use of wheat in bread-making and other food systems. It also has excellent film-forming properties, with gluten films being excellent barriers towards gases such as oxygen and carbon dioxide at low relative humidities (Coltelli et al. 2016). A study of the use of gluten films for wrapping refrigerated strawberries indicated that gluten films are good candidates for controlling the decay of fruits (TanadaPalmu and Grosso, 2005). However, the proteins derived from DDGS (or its intermediate products) are likely to exhibit different properties to those of commercially available wheat gluten, due to effects of enzyme action and processing conditions during DDGS production. 
Earlier, we have carried out the chemical composition of DDGS and wet solids and observed that the protein and lignin contents were lower for wet solids (19.8 and $4.1 \%$ respectively) than DDGS (29.1 and $5.3 \%$ respectively) whereas carbohydrate content was slightly lower for DDGS (68\%) and wet solids (73\%) (Chatzifragkou et al. 2016). The dry matter content of DDGS and wet solids was obtained to be 96.6 and $33.2 \%$ respectively. In terms of crude fat, DDGS and wet solids contained $3.4 \%$ and $2.9 \%$ respectively and ash content was observed to be $3.9 \%$ for DDGS and $2.1 \%$ for wet solids.

Thus, the main objective of the present study was to develop films from DDGSderived gluten, comparing the final dry product with an in-process sample of wet solids to determine whether the final drying step affects the properties of the extracted proteins. To this end, various functional properties of the protein fractions of DDGS and wet solids and their respective films were determined and compared.

\section{Materials and methods}

\subsection{Materials}

DDGS and wet solids were provided by Strathclyde distillery in UK (Chivas Brothers Ltd). The samples were lyophilized in a VirTis Bench Top (USA) freeze-drier for $48 \mathrm{~h}$ at $-55{ }^{\circ} \mathrm{C}$ and stored at $-20^{\circ} \mathrm{C}$. Commercial gluten and ammonium hydroxide was purchased from Sigma Aldrich and glycerol from Fisher scientific. All other chemicals used were of analytical grade. 


\subsection{Film Preparation}

Proteins were extracted from DDGS and wet solids using aqueous ethanol and alkalineaqueous ethanol. The proteins were extracted from DDGS and wet solids by a two step process as explained by Chatzifragkou et al. (2016). The samples (10 g) were mixed with 70 $\%(\mathrm{v} / \mathrm{v})$ aqueous ethanol $(1: 10 \mathrm{v} / \mathrm{w})$ and incubated at $70{ }^{\circ} \mathrm{C}$ for $30 \mathrm{~min}$ under constant stirring, followed by centrifugation $(8000 \times \mathrm{g} ; 15 \mathrm{~min})$. The residue was treated with $70 \%(\mathrm{v} / \mathrm{v})$ of aqueous ethanol $(1: 10 \mathrm{v} / \mathrm{w})$ containing $1.0 \%(\mathrm{w} / \mathrm{v})$ sodium metabisulphite as reducing agent. The samples were incubated at $70{ }^{\circ} \mathrm{C}$ for $30 \mathrm{~min}$ followed by centrifugation $(10000 \times \mathrm{g} ; 10$ $\min$ ) at $25{ }^{\circ} \mathrm{C}$ and second step of extraction was repeated. The concentration of ethanol in the supernatant was reduced to below $20 \%$ (v/v) by diluting with deionised water and placed at $20 \mathrm{oC}$ for $4 \mathrm{~h}$ for precipitation of proteins. The precipitated proteins were centrifuged $(15000 \times$ g; 20 min) at $2{ }^{\circ} \mathrm{C}$, washed with deionised water, lyophilized in a VirTis Bench Top (USA) freeze-drier for $48 \mathrm{~h}$ and stored at $-20{ }^{\circ} \mathrm{C}$. Proteins were also extracted from alkaline-ethanol extraction method. Alkaline conditions were incorporated at the second stage of two-step extraction process, in which aqueous ethanol was mixed with $1.0 \mathrm{M}$ sodium hydroxide $(\mathrm{NaOH})$ and $1.0 \%$ sodium metabisulphite with a solid-to-liquid ratio of 1:10. After centrifugation, extracted proteins were precipitated using hydrochloric acid $(\mathrm{HCl})$ at $\mathrm{pH} 5.5$, collected by centrifugation, washed, lyophilized and stored at $-20{ }^{\circ} \mathrm{C}$. The carbohydrate content in the proteins extracted from DDGS and wet solids were 4.2 and $2.4 \%$ respectively. The molecular masses of extracted proteins were previously determined by SDS-PAGE (Chatzifragkou et al. 2016) and were in the range of 15-50 kDa.

For the preparation of the films, dried protein extracts $(2.5 \mathrm{~g}$ for protein extracted from DDGS and $2.2 \mathrm{~g}$ for those extracted from wet solids) were dispersed in $10 \mathrm{~mL}$ aqueous ethanol solution followed by the addition of $30 \%(\mathrm{w} / \mathrm{w})$ glycerol. The solution was stirred 
continuously $(120 \mathrm{rpm}$ ) after adjusting its $\mathrm{pH}$ to $11.0 \pm 0.5$ (using ammonium hydroxide solution) and temperature at $75{ }^{\circ} \mathrm{C}$, respectively, and then poured into a petri dish and dried at $40{ }^{\circ} \mathrm{C}$. Films were also prepared from commercial gluten (from Sigma Aldrich) using the same procedure. The films obtained from DDGS and wet solids using the aqueous ethanol and alkali aqueous ethanol extraction solvents are referred to as DDGS_EtOH, DDGS_NaOH, wet solids_EtOH and wet solids_NaOH respectively.

\subsection{Colour analysis of films}

The colour of the films was determined using a sph850 spectrophotometer (ColorLite GmbH, Katlenburg-Lindau, Germany) calibrated using a white standard. The parameters measured were $\mathrm{L}^{*}$ (luminescence), $\mathrm{a}^{*}$ (red tone) and $\mathrm{b}^{*}$ (yellow tone) which represent the lightness, red to green and yellow to blue colour dimensions, respectively. The ranges of the colour coordinates were: $\mathrm{L}^{*}-0$ to 100 (black to white), $\mathrm{a}^{*}$ [red (-) to green (+)] and b [(yellow (-) to blue (+)] (Ordidge et al. 2012).

\subsection{Fourier transform infrared analysis (FTIR) of films}

The films were structurally characterised using a Perkin-Elmer spectrum 100 FTIR spectrometer (Perkin-Elmer, UK) equipped with diamond-attenuated total reflectance (ATR) scanning accessory. The spectra were recorded from $4000-500 \mathrm{~cm}^{-1}$ at a resolution of $4 \mathrm{~cm}^{-1}$ and scan frequency of 32 scans.

\subsection{Scanning Electron Microscopy (SEM)}


The surface morphology of the films (at 500x magnification) was determined using FEI Quanta FEG 600 Environmental Scanning Electron Microscope. Films were cut into small pieces and mounted on aluminium stubs with carbon cements, both sides of which are lined with a thick conductive adhesive. The images were taken at an accelerating voltage of $5 \mathrm{kV}$ after coating with gold under vacuum for $180 \mathrm{sec}$ at $40 \mathrm{~mA}$.

\subsection{Thermogravimetric analysis (TGA) of films}

Thermal characterization of the films (10-20 mg) was carried out using a thermogravimetric analyser, TGA Q50 (TA instruments, TA universal analysis software, UK)). Film, placed on a platinum pan was heated from 30 to $800{ }^{\circ} \mathrm{C}$ at a rate of $10{ }^{\circ} \mathrm{C} / \mathrm{min}$. The analysis was performed in a nitrogen atmosphere at a flow rate of $40 \mathrm{~mL} / \mathrm{min}$. The loss of weight of the films was recorded as a function of temperature.

\subsection{Moisture content of films}

The moisture content of the films was determined by heating a previously weighed film in an air-circulating oven (SalvisLab, Thermocentre) at $105{ }^{\circ} \mathrm{C}$ till constant weight was achieved. The weight of the dry sample was recorded and the moisture content calculated.

\subsection{Solubility of films in water and water uptake}

The solubility of the films in water was determined according to Gontard et al. (1992). Briefly, dried films $(2 \times 2 \mathrm{~cm})$ were cut, weighed $\left(\mathrm{W}_{1}\right)$ and soaked in $25 \mathrm{~mL}$ distilled water with gentle agitation (at $60 \mathrm{rpm}$ ) for $1 \mathrm{~h}$ at room temperature. The film was then removed; 
any excess water was wiped off and the film was weighed $\left(\mathrm{W}_{2}\right)$ and dried in an air oven. The weight of the dried films was also noted $\left(\mathrm{W}_{3}\right)$. The solubility in water and the water uptake of the films after $1 \mathrm{~h}$ was calculated using equations (1) and (2) respectively:

$$
\begin{aligned}
& \text { Solubility in water }(\%)=\left(\mathrm{W}_{1}-\mathrm{W}_{3}\right) / \mathrm{W}_{1} \times 100, \\
& \text { Eqater uptake }=\left(\mathrm{W}_{2}-\mathrm{W}_{3}\right) / \mathrm{W}_{3} \times 100
\end{aligned}
$$

\subsection{Water vapour permeability (WVP) of films}

The WVP of the films was determined according to the method described by American Society for Testing and Materials (ASTM, 2013) procedure at $23 \pm 2{ }^{\circ} \mathrm{C}$. Prior to determining water vapour permeability, the films were conditioned at a relative humidity of $11 \pm 5 \%$ at $23 \pm 2{ }^{\circ} \mathrm{C}$ using saturated lithium chloride solution for $48 \mathrm{~h}$. The thickness of the films, measured as an average of ten different points in the film was determined using a hand-held micrometer. Subsequently, films were sealed on a permeation cup containing silica gel (maintained at $0 \%$ relative humidity). The cup with the film was then placed in a desiccator which was maintained at $100 \%$ relative humidity. Water vapour absorbed by the silica gel was passed through the film, and this was measured as the weight gain of the permeation cup. The cups were weighed till steady state conditions were achieved, while the permeability was determined by the following equation:

$$
\text { Permeability }\left(\text { g. } \mathrm{m}^{-1} \mathrm{~s}^{-1} \mathrm{~Pa}^{-1}\right)=\mathrm{W} \times \mathrm{x} /\left[\mathrm{A} \times \mathrm{t} \times\left(\mathrm{P}_{1}-\mathrm{P}_{2}\right)\right] \quad \text { Eq. (3), }
$$

where $\mathrm{W}$ is the weight gain of the permeability cup, $\mathrm{x}$ denotes the thickness of the film, $\mathrm{A}$ is the area of the exposed film surface, $t$ is the time required to achieve the steady state condition and $\left(\mathrm{P}_{1}-\mathrm{P}_{2}\right)$ is the vapour pressure differential across the film. 


\subsection{Surface hydrophobicity of films}

The surface hydrophobicity of the films was determined using a contact angle meter, Theta lite from Attention (Stockholm, Sweden) at $23 \pm 2{ }^{\circ} \mathrm{C}$. The measurement was carried out on the smooth surface of the films (lower surface of the casted film) which was kept under the same environmental conditions to avoid the interference of the moisture exchange on the film surface around the water droplet.

\subsection{Mechanical properties of films}

The thickness of rectangular strips of films (length $100 \mathrm{~mm}$ and width $25 \mathrm{~mm}$ ) and their cross-sectional area was determined using a hand-held micrometer. The film specimens were then conditioned at a relative humidity of $50 \pm 5 \%$ (using saturated calcium nitrate solution) at $23 \pm 2{ }^{\circ} \mathrm{C}$ for $24 \mathrm{~h}$. The mechanical properties of the films were determined using Steven's compression response analyser with a cross head speed of $60 \mathrm{~mm} / \mathrm{minute}$. The initial grip separation was $100 \mathrm{~mm}$. During the test, a peak load was developed and tensile strength was determined by dividing the maximum peak load with the cross-sectional area of the film. The elongation at break $(\mathrm{EAB})$ of the films was determined by dividing the film extension at the point of break with the initial gauge length of the film. The tensile strength and elongation at break values were determined as the averages of triplicates according to the ASTM standard method (2009).

\subsection{Statistical analysis}


The data presented are the mean values of at least three independent experiments, while the statistical analysis of the data was carried out using the SPSS software package. Duncan's multiple range test was employed to compare the mean values.

\section{Results and Discussion}

\subsection{Colour of the films}

Colour is an important parameter, which plays a major role in determining the end-use of the polymeric film. The films obtained from DDGS protein were dark and opaque compared to those from wet solids protein and gluten films. The colour parameters of the DDGS, wet solids and commercial gluten films are presented in Table 1. It can be noted that the luminescence $\left(\mathrm{L}^{*}\right)$ parameter of the films followed the order DDGS > wet solids > gluten films. A lower L* value for DDGS films indicated the darker colour of the films compared to wet solids and gluten films. Such darkening could be due to Maillard reactions occurring when DDGS is subjected to high temperatures during the final drum drier stage of the production process (Dangaran et al. 2009). These findings are in agreement with the study of Cromwell et al. (1993) in which colour analysis of DDGS from different sources resulted in low $\mathrm{L}^{*}$ values ranging from 29-53, indicating their darker colour.

The redness parameter (a) was highest for the wet solids-derived film (17.5 for WS_NaOH) and lowest for the film prepared using commercial wheat gluten (0.5). The redness and yellowness parameters exhibited by the DDGS films were significantly lower compared to those of wet solid-derived films.

Colour is an important parameter deciding the end-use of the product. For food packaging applications (including edible films), the film needs to be transparent and 
colourless since appearance has an important role in deciding product quality. However, the negative effect of colour of the film on commercial applications could potentially be addressed by using decolourising agents. On the other hand, colour does not have much role in packaging applications such as carrier bags, soluble films for detergent tablets, agricultural applications etc.

\subsection{Structural characteristics and surface morphology of films}

The FTIR spectra of the films prepared from DDGS, wet solids and gluten are shown in Figure 1a. All films exhibited characteristic protein peaks such as amide I peak at $1651 \mathrm{~cm}^{-}$

${ }^{1}$ (due to the $\mathrm{C}=\mathrm{O}$ stretching vibration of the peptide group), amide II at $1541 \mathrm{~cm}^{-1}$ (which can be attributed to $\mathrm{CN}$ stretching and in-plane $\mathrm{N}-\mathrm{H}$ deformation modes) and amide III peak at $1350-1200 \mathrm{~cm}^{-1}$ (due to $\mathrm{N}-\mathrm{H}$ in-plane bending vibrations, C-N stretching and some contributions from $\mathrm{C}-\mathrm{C}$ stretching and $\mathrm{C}-\mathrm{O}$ bending of proteins). A broad peak was also observed in the region $3500-3000 \mathrm{~cm}^{-1}$ due to the combined $\mathrm{O}-\mathrm{H}$ and $\mathrm{N}-\mathrm{H}$ stretching frequencies of hydroxyl and amine groups of proteins. The medium intensity peaks observed between 2854 and $2921 \mathrm{~cm}^{-1}$ can be attributed to the aliphatic $\mathrm{C}-\mathrm{H}$ stretching frequencies.

Information on the secondary structure of the proteins can be obtained from the amide I and amide II regions in the FTIR spectra. In the present study, the amide I peak for gluten films was at $1664 \mathrm{~cm}^{-1}$. However, the amide I peaks for DDGS and wet solids films were broad bands with peak positions at 1651 and $1624 \mathrm{~cm}^{-1}$ (Figure 1b). The amide I peak at 1664 $\mathrm{cm}^{-1}$ indicated the predominance of $\alpha$-helical conformation for films prepared from commercial gluten and the broad peak in the region 1650 and $1624 \mathrm{~cm}^{-1}$ revealed the existence of combined $\alpha$-helical and the $\beta$-sheet conformations for DDGS and wet solids films. Earlier studies by Carbonaro and Nukara (2010) and Surewicz et al. (1993) suggested 
that the occurrence of amide I bands at $1654 \mathrm{~cm}^{-1}$ and $1612-1640 \mathrm{~cm}^{-1}$ confirmed the presence of $\alpha$-helical and $\beta$-sheet conformations, respectively. Thus, we observed differences in the secondary structures of the proteins derived from DDGS and wet solids compared to gluten. Our observation is in agreement with previous studies which showed that the modification of wheat gluten by dry-heating can result in alteration in the secondary structure of proteins (Zhang et al. 2012). Moreover, the peaks at $1039 \mathrm{~cm}^{-1}$ and a relatively small peak at $1745 \mathrm{~cm}^{-1}$ in DDGS and wet solids' film could be attributed to the C-O (C6-skeletal) vibrations in cellulose component and $\mathrm{C}=\mathrm{O}$ group in hemicellulose and lignin respectively (Zarrinbakhsh et al. 2013). Earlier we have characterised the proteins extracted from DDGS and wet solids in terms of their carbohydrate content and observed 4.2 and $2.4 \%$ respectively (Chatzifragkou et al. 2016).

In the case of films prepared from DDGS and wet solids, amide II bands were observed in the region 1541 and $1540 \mathrm{~cm}^{-1}$ respectively, which indicated the existence of a parallel $\beta$-sheet conformation. Zhuang et al. (2009) reported that peptides possessing antiparallel $\beta$-sheet structures exhibit strong amide II bands in the region $1510-1530 \mathrm{~cm}^{-1}$ and those possessing parallel $\beta$-sheet structures exhibit peaks at a slightly higher frequency of 1530-1550 $\mathrm{cm}^{-1}$. Thus, comparison of the FTIR bands of the developed films revealed differences in the secondary structures of DDGS and wet solids films compared to gluten films. Similar changes in the secondary structure of proteins extracted from DDGS were reported by Azarfar et al. (2013).

Scanning electron micrographs of the films are presented in Figure 2 (A-E). Clear differences can be seen in the surface morphology of the DDGS and wet solids gluten films in comparison with gluten films. The latter appeared relatively smooth and homogenous whereas surfaces of the DDGS, wet solid films were heterogeneous, rough and uneven, with 
small voids. These voids are expected to act as channels facilitating the absorption, diffusion and permeation of moisture into and through the films (Hager et al. 2012). The presence of voids could be an indication of the weaker intermolecular association between protein chains. With regard to their functional properties, the presence of cracks and holes is expected to increase the surface area of contact with water vapour or moisture.

\subsection{Thermogravimetric analysis of films}

Thermogravimetric analysis of the films was carried out in order to follow their thermal degradation patterns. The thermograms are shown in Figure $3(a, b)$. An initial weight loss step was observed for all films and corresponded to the evaporation of water. The largest weight loss step corresponded to the degradation of protein and took place between 100-500 ${ }^{\circ} \mathrm{C}$. The weights retained by the DDGS and wet solid films in the region $100-500{ }^{\circ} \mathrm{C}$ were lower than those of the gluten films (Table 2). This observation is consistent with the lower thermal stability of the DDGS and wet solids proteins compared to gluten, which is clearly demonstrated by the derivative TGA (DTGA) peak [Figure $4(a, b)]$.

The pattern of degradation of the DDGS and wet solids films also differed compared to gluten films in the region $100-500{ }^{\circ} \mathrm{C}$. The DTGA peaks in all three films clearly indicated that the degradation of the protein components in the film took place between 293 and $310^{\circ} \mathrm{C}$. However, in the case of DDGS and wet solids films, shoulder peaks were also observed before protein degradation took place $\left(<300{ }^{\circ} \mathrm{C}\right)$. These shoulder peaks could be the result of degradation of trace amounts of carbohydrate components which may have been extracted together with the proteins from the DDGS and wet solids. These peaks were not observed in gluten films. In an earlier study, we characterised the carbohydrate content of the

protein extracts, giving values of $4.2 \%$ (corresponding to glucose $-2.1 \%$, xylose $-1.5 \%$ 
and arabinose $-0.6 \%$ ) for the protein extracts from DDGS and $2.4 \%$ (corresponding to glucose $-1.2 \%$, xylose $-0.9 \%$ and arabinose- $0.3 \%$ ) for the protein extracts from wet solids (Chatzifragkou et al. 2016). Thermogravimetric analysis of karifin proteins extracted from sorghum DDGS also exhibited multiple degradation peaks in the same region due to degradation of components of different thermal stability in the material (Wang et al. 2009). Thermal degradation studies of hemi-cellulose rich film extracted from distillers' grains exhibited two major degradation peaks corresponding to hemi-cellulose and protein components, respectively, which are consistent with our observations (Xiang et al. 2014). Our observations are also in agreement with Zarrinbakhsh et al. (2011) who reported that a high level of thermal degradation of DDGS and polyhydroxy(butyrate-co-valarate) based biocomposite occurred between $130-530{ }^{\circ} \mathrm{C}$, a temperature region in which the degradation of the major components in DDGS such as proteins, hemi-cellulose, cellulose and some portions of lignin occurred.

A small degradation was also evident in thermograms of the films at $225-237{ }^{\circ} \mathrm{C}$, which corresponded to the degradation of glycerol present in the film $(30 \% \mathrm{w} / \mathrm{w}$ glycerol was added as the plasticiser in all films). The final degradation stage (from $500-800^{\circ}$ ) represented the degradation of lignin and complex high molecular weight components present in the film.

\subsection{Moisture content of films}

Gluten-based films are known for their moisture sensitivity due to the presence of hydrophilic amino acids in the protein chains. Moreover, the presence of hydrophilic plasticizers, which constitute an important additive in the film-forming solution, is also responsible for the higher sensitivity of films towards moisture. The moisture contents of the films ranged from 
10.2 to $19.8 \%$ (Table 3). Among the DDGS and wet solids films, the moisture content was lower for the DDGS film. Statistical analysis of the data also indicated significant differences among the moisture contents of DDGS and wet solid films. However, no significant differences were observed in the moisture contents of films produced using different extraction methods. i.e. DDGS_EtOH and DDGS_NaOH, as well as WS_EtOH, WS_NaOH films.

Moisture content determination is particularly important since most of the properties of the films depend on this factor rather than on the processing conditions of the films. Moisture can penetrate between the protein chains, increasing the hydrophilic nature of the films and interacting with the polar amino acids leading to changes in the film properties such as higher permeability to water vapour (Schmid, 2013). This is because water molecules can lead to conformational changes in the macromolecular structure of protein chains (Romero-Bastida et al. 2004).

\subsection{Water solubility and absorption of films}

The solubility of polymer films in water is an indication of the interactions between the protein chains and is considered an important property for protein-based films. In certain applications, such as edible films, solubility before consumption is beneficial, whereas in other cases, i.e. food packaging applications, the films are expected to maintain their integrity and water resistance (Pérez-Gago et al. 1999).

In the present study, the solubility of the films ranged from $17-41 \%$, following the order DDGS_NaOH > DDGS_EtOH > WS_NaOH > WS_EtOH > gluten films. Water solubility was greater for DDGS films compared to wet solids films. It was also observed that DDGS films exhibited a softening effect when soaked in water after some time. However, this effect was less pronounced in other films. The lower solubility of the wet solids films 
compared to DDGS films can be attributed to the higher contents of glutamic acid and proline in the wet solids protein extracts, as reported by Chatzifragkou et al. (2016). An increase in glutamine content in wheat gluten proteins was responsible for the numerous hydrogen bonding interactions between the peptide chains which inturn contributed to increased protein-protein interactions (Gontard et al. 1993). Thus the intermolecular interactions as a result of more hydrogen bonds might have contributed to the lower solubility of films derived from wet solids. On the contrary, the higher solubility of DDGS films can be related to the reduced inter-molecular interaction such as hydrogen bonding and disulphide interactions between the protein chains.

Water absorption is an efficient and simple qualitative analysis for determining the cross-linking density of polymer films and bioplastics (Verbeek and van den Berg, 2010). Generally, a highly cross-linked and rigid polymer network exhibits reduced water absorption. The water absorption of films was determined after soaking in water for $1 \mathrm{~h}$ and the values obtained were higher for the films prepared from DDGS compared to those prepared from wet solids and gluten (Table 3). However, no significant differences were observed for water absorbency between the films prepared using extracts made with aqueous ethanol and alkaline aqueous ethanol, indicating that the protein extraction method did not have any effect on the water absorbency of films. The water absorption of the films ranged from 129.8 to $196.5 \%$. As previously noted, a reduced intermolecular interactions such as hydrogen bonding and disulphide interactions between the peptide chains of gluten extracted from DDGS was the major reason for the observed higher water uptake for these films compared to those prepared from wet solids and gluten. Moreover, soaking DDGS films in water has been reported to increase protein chain mobility due to the low intermolecular cross-linking between protein chains, thereby reducing the three-dimensional rearrangement of the network during water absorption (Angellier-Coussy et al. 2011). The higher 
hydrophilicity of the films derived from DDGS may also be responsible for their higher water uptake of these films. In contrast, the intermolecular interaction between protein chains might be higher for wet solids and gluten films which is reflected in their lower water uptake.

\subsection{Water vapour permeability and surface hydrophobicity of films}

The permeability of a polymer film is influenced by several factors such as hydrophilicity, presence of voids on the surface, steric hindrance and tortuosity of the material (Wang and Padua, 2005). The values for water vapour permeability (WVP) of the developed films are presented in Table 3. No significant differences were observed between the WVP of DDGS and wet solids films, however, the values were higher compared to the gluten films. The hydrophilic nature of the DDGS and wet solids films in combination with the presence of voids on their surfaces (as seen from the SEM images) were considered to be the major reasons for their high permeability. However, the lower permeability of gluten films can be attributed to the formation of covalent cross-links and the reduction in hydrophilicity (Ali et al. 1997). The hydrophilic nature of the films and the presence of voids can in turn affect the solubility and diffusion of water molecules in the film matrix. Hydrophilic films have a tendency to absorb water which can act as a plasticizer for protein-based films (Wang and Padua, 2004). These plasticisers can increase the free volume between the protein chains facilitating higher mobility of the polymer chain segments and thereby increasing the permeability of water vapour through the films (Ellis, 1998; Levine and Slade, 1990).

The surface hydrophobicity of films was determined from their contact angle values following the sessile drop method. In the case of hydrophilic materials, the liquid drop is attracted by the solid surface which results in an increase in the surface energy and spreading out of the drop on the surface exhibiting a contact angle of $0^{\circ}$. In other words, a hydrophilic 
film allows the water to enter the pores leading to better wetness, adhesiveness and higher surface energy. Higher contact angle values are characteristic of the hydrophobic nature of the film. As it can be seen from Figure 5, the contact of the films ranged from $20-55^{\circ}$. The contact angle values of gluten films extracted from DDGS and wet solids were lower than those of the films prepared from commercial gluten, indicating that the DDGS and wet solids films exhibited more affinity for water as a result of their greater hydrophilicity. Apart from the hydrophilicity of the films, the contact angle of water also depends on surface roughness, porosity and processing conditions such as temperature (Yin et al. 2007; Chau et al. 2009; Wang et al. 2014). Although hydrophilicity is not an ideal property for the application of films as packaging materials, this property can be exploited for potential agricultural uses, such as for the development of polymer matrices as controlled release agents of fertilizers or nutrients (soil conditioners) for the soil.

\subsection{Mechanical properties of films}

The tensile strength and elongation at break (\%) values of DDGS, wet solids and gluten films are presented in Figure $6(\mathrm{a}, \mathrm{b})$. Although there was little difference in tensile strength between the DDGS and wet solids films, the values for both were considerably lower than those for gluten films. The tensile strength ranged from 0.27 to $0.32 \mathrm{MPa}$ for DDGS and wet solids films, compared to $0.6 \mathrm{MPa}$ for gluten films. The elongation at break values for the DDGS $(10 \%)$ and wet solids $(11.4 \%)$ films were also significantly lower than those of gluten films $(54 \%)$. It should also to be noted that there was no significant effect of protein extraction method on the mechanical properties of the films. The mechanical properties of gluten-based films are determined by the structure of the protein. Weaker mechanical properties of protein polymers are associated with decreased intermolecular associations of 
the protein chains. The main interactions that stabilise the gluten structure are disulphide cross-links and hydrogen bonds (Ture et al. 2011). Cuq et al. (2000) have previously observed that increasing the cross-linking of the protein network by intermolecular covalent bonds increased the tensile strength of gluten films. Thus, the variation in the properties of DDGS, wet solids and gluten films could be attributed to the differences in the ability of gluten proteins to establish inter- and intra-molecular interactions. Moreover, increased hydrophilicity of the protein chains minimise intermolecular interactions within the network, with concomitant increase in the free volume. This leads to an increased backbone chain segmental mobility and chain flexibility (Lens et al. 2003).

\section{Conclusion}

DDGS and wet solids protein fractions were utilised as starting material for the development of films. The inherent properties in the extracted proteins were evident in their film forming ability. Structural characterisation of the films revealed differences in their secondary structure compared to gluten films. DDGS and wet solids films exhibited an uneven surface with voids and cracks and higher water sensitivity compared to gluten films. However the functional and mechanical properties of the films were not affected by the protein extraction techniques (aqueous ethanol vs alkaline aqueous ethanol). Their poor mechanical properties and high water vapour permeability limits the application of DDGS and wet solids films as biodegradable packaging materials. However, based on their hydrophilicity, the developed films have potential in agricultural and horticultural applications, as controlled release matrices and soil conditioners.

\section{Acknowledgements}


The authors would like to acknowledge the Integrated Biorefining Research and Technology Club (IBTI) of the UK Biotechnology and Biological Sciences Research Council (BBSRC) for their financial support on a collaborative research project entitled "Development of a process scheme for the production of high value functional products from DDGS" (BB/J019429/1-University of Reading; BB/J019380/1 - Rothamsted Research). Rothamsted Research receives grant-aided support from the Biotechnology and Biological Sciences Research Council of the UK

\section{References}

Ali, Y., Ghorpade, V.M., Hanna, M.A., 1997. Properties of thermally-treated wheat gluten films. Ind. Crop. Prod. 6, 177-184.

Angellier-Coussy, H., Gastaldi, E., Gontard, N., Guillard, V., 2011. Influence of processing temperature on the water vapour transport properties of wheat gluten based agromaterials. Ind. Crop. Prod. 33, 457-461.

ASTM, 2009. D882-02. Standard test methods for tensile properties of thin plastic sheeting, in Annual book of ASTM standards., American Society for Testing and Materials., Philadelphia, PA, pp. 1-10.

ASTM. 2013. E96M-13 Standard test methods for water vapour transmission of materials, in Annual book of ASTM standards. American Society for Testing and Materials., Philadelphia, PA, pp. 1-12.

Azarfar, A., Jonker, A., Yu, P., 2013. Protein structures among bio-ethanol co-products and its relationships with ruminal and intestinal availability of protein in dairy cattle. Int. J. Mol. Sci. 14, 16802-16816. 
Carbonaro, M., Nucara, A., 2010. Secondary structure of food proteins by fourier transform spectroscopy in the mid-infrared region. Amino Acids, 38, 679-690.

Chatzifragkou, A., Prabhakumari, P.C., Kosik, O., Lovegrove, A., Shewry, P.R., Charalampopoulos, D., 2016. Extractability and characteristics of proteins deriving from wheat DDGS. Food Chem. 198, 12-19.

Chau, T.T., Bruckard, W.J., Koh, P.T.L., Nguyen, A.V., 2009. A review of factors that affect contact angle and implications for flotation practice. Adv. Colloid. Interfac. 150, 106-115.

Coltelli, M-B., Wild, F., Bugnicourt, E., Cinelli, P., Lindner, M., Schmid, M., Weckel, V., Muller, K., Rodriguez, P., Staebler, A., Rodriguez-Turienzo, L., lazzeri, A., 2016. State of art in the development and properties of protein-based films and coatings and their applicability to cellulose based products. An extensive review. Coatings. 6, 1-59.

Cromwell, G.L., Herkelman, K.L., Stahly, T.S., 1993. Physical, chemical and nutritional characteristics of distillers dried grains with solubles for chicks and pigs. J. Anim. Sci. 71, 679-686.

Cuq, B., Boutrot, F., Redl, A., Lullien-Pellerin, V., 2000. Study of the temperature effect on the formation of wheat gluten network: Influence on mechanical properties and protein solubility. J. Agric. Food Chem. 48, 2954-2959.

Dangaran, K., Tomasula, P.M., Qi, P., 2009. Structure and function of protein-based edible films and coatings, in: Embuscado, M.E., Huber, K.C. (Eds.), Edible films and coating for food applications. Springer., New York, pp. 25-56.

Ellis, T. S., 1998. Moisture-induced plasticization of amorphous polyamides and their blends. J. Appl. Polym. Sci. 36, 451-466. 
Gontard, N., Guilbert, S., Cuq, J-L., 1992. Edible wheat gluten films: Influence of the main process variables on film properties using response surface methodology. J. Food Sci. 57, 190-199.

Gontard, N., Guilbert, S., Cuq, J.L., 1993. Water and glycerol as plasticizers affect mechanical and water vapor barrier properties of an edible wheat gluten film. J. Food Sci. 58, 206-211.

Hager, A-S., Katleen, J.R., Arendt, E.K., 2012. Influence of tannic acid and gallic acid on the mechanical and barrier properties of wheat gluten films. J Agric. Food Chem. 60, 6157-6163. Hu, C., Reddy, N., Yan, K., Yang, Y., 2011. Synthesis and characterization of highly flexible thermoplastic films from cyanoethylated corn distillers dried grains with solubles. J. Agric. Food Chem. 59, 1723-1728.

Julson, J.L., Subbarao, G., Stokke, D.D., Gieselman, H.H., Muthukumarappan, K., 2004. Mechanical properties of biorenewable fiber/plastic composites. J. Appl. Polym. Sci. 93, 2484-2493.

Lens, J.P., de Graaf, L.A., Stevels, W.M., Dietz, C.H.J.T., Verhelst, K.C.S., Vereijken, J.M., Kolster, P., 2003. Influence of processing and storage conditions on the mechanical and barrier properties of films cast from aqueous wheat gluten dispersions. Industrial Crops and Products, 17, 119-130.

Levine, H., Slade, L., 1990. Influence of the glassy and rubbery states on the thermal, mechanical, and structural properties of dough and baked products, in: Faridi, H., Faubion, J.M. (Eds.), Dough Rheology and Baked Product Texture. Springer., Boston, MA, pp. 157330. 
Li, Y., Sun, X.S., 2011. Mechanical and thermal properties of biocomposites from poly(lactic acid) and DDGS. J. Appl. Polym Sci. 121, 589-597.

Muniyasamy, S., Reddy, M.M., Misra, M., Mohanty, A., 2013. Biodegradable green composites from bioethanol co-product and poly(butylene adipate-co-terephthalate). Ind. Crop. Prod. 43, 812-819.

OECD-FAO, 2009. OECD_FAO Agricultural Outlook 2009-2018, OECD Publishing. OECD-FAO, 2017. OECD_FAO Agricultural Outlook 2017-2026, OECD Publishing.

Ordidge, M., García-Macías, P., Battey, N.H., Gordon, M.H., John, P., Lovegrove, J.A., Vysini, E., Wagstaffe, A., Hadley, P., 2012. Development of colour and firmness in strawberry crops is UV light sensitive, but colour is not a good predictor of several quality parameters. J. Sci. Food Agr. 92, 1597-1604.

Pérez-Gago, M.B., Nadaud, P., Krochta, J.M., 1999. Water vapor permeability, solubility, and tensile properties of heat-denatured versus native whey protein films. J. Food Sci. 64, 1034-1037.

Reddy, N., Shi, Z., Temme, L., Xu, H., Xu, L., Hou, X., Yang, Y., 2014. Development and characterization of thermoplastic films from sorghum distillers dried grains grafted with various methacrylates. J. Agric. Food Chem. 62, 2406-2411.

Romero-Bastida, C.A., Flores-Huicochea, E., Martin-Polo, M.O., Velazques, G., Torres, J.A., 2004. Compositional and moisture content effects on the biodegradability of zein/ethylcellulose film. J. Agric. Food Chem. 52, 2230-2235.

Schmid, M., 2013. Properties of cast films made from different ratios of whey protein isolate, hydrolysed whey protein isolate and glycerol. Materials. 6, 3254-3269. 
Surewicz, W.K., Mantsch, H.H., Chapman, D., 1993. Determination of protein secondary structure by fourier transform infrared spectroscopy: A critical assessment. Biochemistry 32, 389-394.

Tanada-Palmu, P.S., Grosso, C.R.F., 2005. Effect of edible wheat gluten-based films and coatings on refrigerated strawberry (Fragaria ananassa) quality. Postharvest Biol. Tec. 36, 199-208.

Tatara, R.A., Rosentrater, K.A., Suraparaju, S., 2009. Design properties for molded, cornbased DDGS-filled phenolic resin. Ind. Crop. Prod. 29, 9-15.

Ture, H., Gallstedt, M., Kuktaite, R., Johansson, E., Hedenqvist, M.S., 2011. Protein network structure and properties of wheat gluten extrudates using a novel solvent-free approach with urea as a combined denaturant and plasticiser. Soft Matter, 7, 9416-9423.

Verbeek, C.J.R., van den Berg, L.E., 2010. Extrusion processing and properties of proteinbased thermoplastics. Macromol. Mater. Eng. 295, 10-21.

Wang, Y., Padua, G.W., 2004. Water sorption properties of extruded zein films. J. Agric. Food Chem. 2004, 52, 3100-3105.

Wang, Q., Padua, G.W., 2005. Properties of zein films coated with drying oils. J. Agric. Food Chem. 53, 3444-3448.

Wang, Y., Tilley, M., Bean, S., Sun, X.S., Wang, D., 2009. Comparison of methods for extracting Kafirin proteins from sorghum distillers dried grains with solubles. J. Agric. Food Chem. 57, 8366-8372. 
Wang, Z., Li, Y., Jiang, L., Qi, B., Zhou, L., 2014. Relationship between secondary structure and surface hydrophobicity of soybean protein isolate subjected to heat treatment. Journal of Chemistry, 2014, 1-10.

Wu, F., Munkvold, G.P., 2008. Mycotoxins in ethanol co-products: Modeling economic impacts on the livestock industry and management strategies. J. Agric. Food Chem. 56, 39003911.

Xiang, Z., Watson, J., Tobimatsu, Y., Runge, T., 2014. Film-forming polymers from distillers' grains: structural and material properties. Ind. Crop. Prod. 59, 282-289.

Xu, W., Reddy, N., Yang, Y., 2009. Extraction, characterization and potential applications of cellulose in corn kernels and distillers' dried grains with solubles (DDGS). Carbohydr. Polym. 76, 521-527.

Yin, S.W., Tang, C.H., Wen, Q.B., Yang, X.Q., 2007. Properties of cast films from hemp (Cannabis sativa L.) and soy protein isolates, A comparative study. J. Agric. Food Chem. 55, 7399-7404.

Zarrinbakhsh, N., Mohanty, A.K., Misra, M., 2013. Fundamental studies on water-washing of the corn ethanol coproduct (DDGS) and its characterisation for biocomposite applications. Biomass Bioenergy. 55, 251-259.

Zarrinbakhsh, N., Misra, M., Mohanty, A.K., 2011. Biodegradable green composites from distiller's dried grains with solubles (DDGS) and a polyhydroxy(butyrate-co-valerate) (PHBV)-based bioplastic. Macromol. Mater. Eng. 296, 1035-1045.

Zhang, H., Claver, I.P., Li, Q., Zhu, K., Peng, W., Zhou, H., 2012. Structural modification of wheat gluten by dry heat-enhanced enzymatic hydrolysis. Food Technol. Biotechnol. 50, 5358. 
Zhuang, W., Hayashi, T., Mukamel, S., 2009. Coherent multidimensional vibrational spectroscopy of biomolecules; Concepts, simulations and challenges. Angewandte Chemie. Int. Edit. 48, 3750-3781.

\section{Figure captions}

Figure 1. FTIR spectra of (A) DDGS, wet solids and gluten films (B) Zoomed images of amide I and amide II regions of DDGS, wet solids and gluten films

Figure 2. Scanning electron micrographs (at magnification of 500×) of (A) film prepared from gluten, (B) DDGS derived protein film (obtained by ethanol extraction), (C) DDGS derived protein film (obtained by alkaline-ethanol extraction), (D) wet solids derived protein film (obtained by ethanol extraction) and (E) wet solids derived protein film (obtained by alkaline-ethanol extraction)

Figure 3. Thermograms of films produced from (a) aqueous ethanol extracted protein from DDGS and wet solids (b) alkaline-aqueous ethanol extracted DDGS and wet solids and gluten

Figure 4. Derivative of thermogravimetric analysis peaks of films produced from (a) aqueous ethanol extracted protein from DDGS and wet solids (b) alkaline-aqueous ethanol extracted protein from DDGS and wet solids and gluten

Figure 5. Contact angles of films produced from DDGS, wet solids' proteins and gluten Figure 6. Mechanical properties of films (a) Tensile strength of films prepared from gluten proteins extracted from DDGS, wet solids and gluten and (b) Elongation at break (\%) of films prepared from gluten proteins extracted from DDGS, wet solids and gluten 
Table 1. Colour analysis of films

\begin{tabular}{|c|c|c|c|}
\hline Film sample & $\mathrm{L}^{* a}$ & $\mathrm{a}^{a}$ & $\mathrm{~b}^{a}$ \\
\hline DDGS_EtOH & $20.2 \pm 1.0^{\mathrm{a}}$ & $0.91 \pm 0.6^{\mathrm{a}}$ & $5.9 \pm 1.0^{\mathrm{a}}$ \\
\hline DDGS_NaOH & $10.9 \pm 1.1^{\mathrm{b}}$ & $0.93 \pm 2.9^{\mathrm{a}}$ & $10.0 \pm 4.5^{\mathrm{a}, \mathrm{b}}$ \\
\hline Wet solids_EtOH & $37.3 \pm 0.1^{\mathrm{c}}$ & $15.2 \pm 0.2^{\mathrm{b}}$ & $27.7 \pm 0.6^{\mathrm{c}}$ \\
\hline Wet solids_NaOH & $35.7 \pm 0.01^{\mathrm{c}}$ & $17.5 \pm 0.3^{b}$ & $34.1 \pm 2.0^{c}$ \\
\hline Gluten & $83.5 \pm 0.2^{\mathrm{d}}$ & $-0.45 \pm 0.1^{\mathrm{a}}$ & $17.1 \pm 0.4^{\mathrm{b}}$ \\
\hline
\end{tabular}


Table 2. Weights retained by films at different degradation stages

\begin{tabular}{|c|c|c|c|}
\hline Film & $\begin{array}{c}\text { No. of degradation } \\
\text { stages }\end{array}$ & $\begin{array}{c}\text { Temperature } \\
\left({ }^{\circ} \mathrm{C}\right)\end{array}$ & $\begin{array}{c}\text { Weight } \\
\text { retained }(\%)^{b}\end{array}$ \\
\hline \multirow[t]{3}{*}{ DDGS_EtOH } & 1 & $30-65$ & 98.3 \\
\hline & 2 & $65-500$ & 16.2 \\
\hline & 3 & $500-800$ & 5.4 \\
\hline \multirow[t]{3}{*}{ DDGS_NaOH } & 1 & $30-58.2$ & 98.9 \\
\hline & 2 & $58-500$ & 14.6 \\
\hline & 3 & $500-800$ & 10.6 \\
\hline \multirow[t]{3}{*}{ Wet solids_EtOH } & 1 & $30-130$ & 95 \\
\hline & 2 & $130-500$ & 13.72 \\
\hline & 3 & $500-800$ & 8.6 \\
\hline \multirow[t]{3}{*}{ Wet solids_NaOH } & 1 & $30-66.3$ & 98.0 \\
\hline & 2 & $66.3-500$ & 10.7 \\
\hline & 3 & $500-800$ & 6.9 \\
\hline \multirow[t]{3}{*}{ Gluten } & 1 & $30-130$ & 96 \\
\hline & 2 & $130-500$ & 18.5 \\
\hline & 3 & $500-800$ & 13.8 \\
\hline
\end{tabular}

$b_{\text {the values denote the weights retained by the films after major degradation stages }}$ 
Table 3. Water sensitive properties of films

\begin{tabular}{|c|c|c|c|c|}
\hline Film & $\begin{array}{c}\text { Moisture } \\
\text { content }(\%)^{c}\end{array}$ & $\begin{array}{l}\text { Solubility in water } \\
(\%)^{c}\end{array}$ & $\begin{array}{c}\text { Water uptake } \\
(\%)^{c}\end{array}$ & $\begin{array}{l}\text { WVP } \times 10^{-10} \\
\left(\text { g. } \mathrm{m}^{-1} \mathrm{~s}^{-1} \mathrm{~Pa}^{-1}\right)^{c}\end{array}$ \\
\hline DDGS_EtOH & $10.2 \pm 1.20^{\mathrm{a}}$ & $32.3 \pm 2.1^{\mathrm{a}}$ & $196.2 \pm 3.1^{\mathrm{a}}$ & $4.56 \pm 0.60^{\mathrm{a}}$ \\
\hline DDGS_NaOH & $14.2 \pm 1.0^{\mathrm{a}}$ & $41.8 \pm 0.8^{b}$ & $196.5 \pm 6.8^{a}$ & $4.63 \pm 0.30^{\mathrm{a}}$ \\
\hline Wet solids_EtOH & $19.8 \pm 0.7^{b}$ & $23.8 \pm 0.3^{\mathrm{c}}$ & $129.7 \pm 2.7^{b}$ & $4.70 \pm 0.35^{\mathrm{a}}$ \\
\hline Wet solids_NaOH & $18.9 \pm 1.7^{b}$ & $24.2 \pm 1.9^{\mathrm{c}}$ & $132.2 \pm 4.0^{\mathrm{b}}$ & $4.92 \pm 0.46^{\mathrm{a}}$ \\
\hline Gluten & $17.1 \pm 1.30^{\mathrm{a}, \mathrm{b}}$ & $17.0 \pm 1.6^{\mathrm{d}}$ & $130.9 \pm 1.3^{\mathrm{b}}$ & $2.46 \pm 0.44^{b}$ \\
\hline
\end{tabular}

${ }^{c}$ Mean and standard deviation of replicates. Mean values in the same column with different superscript letters are significantly different $(\mathrm{p}<0.05)$. 

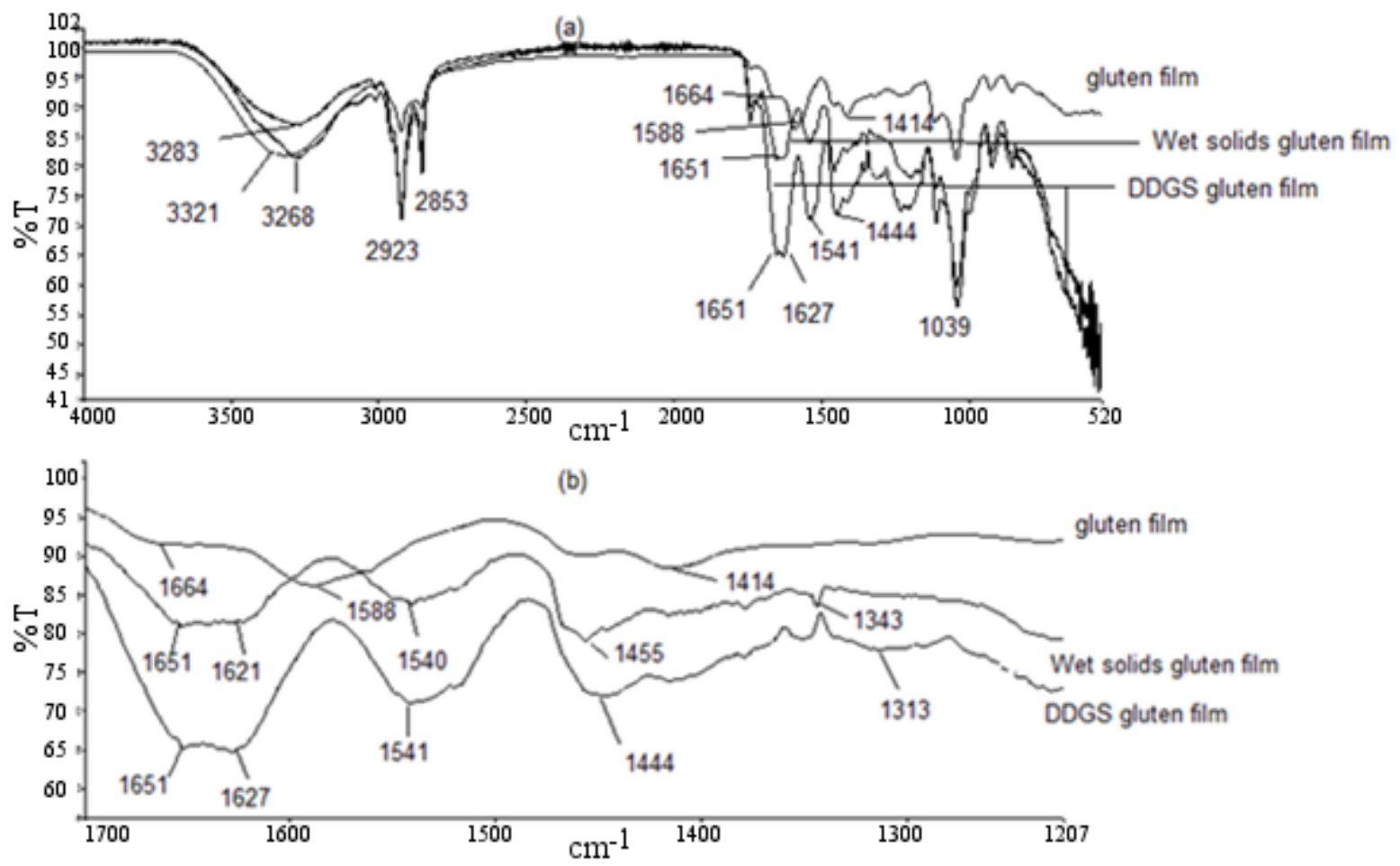

Fig 1. 


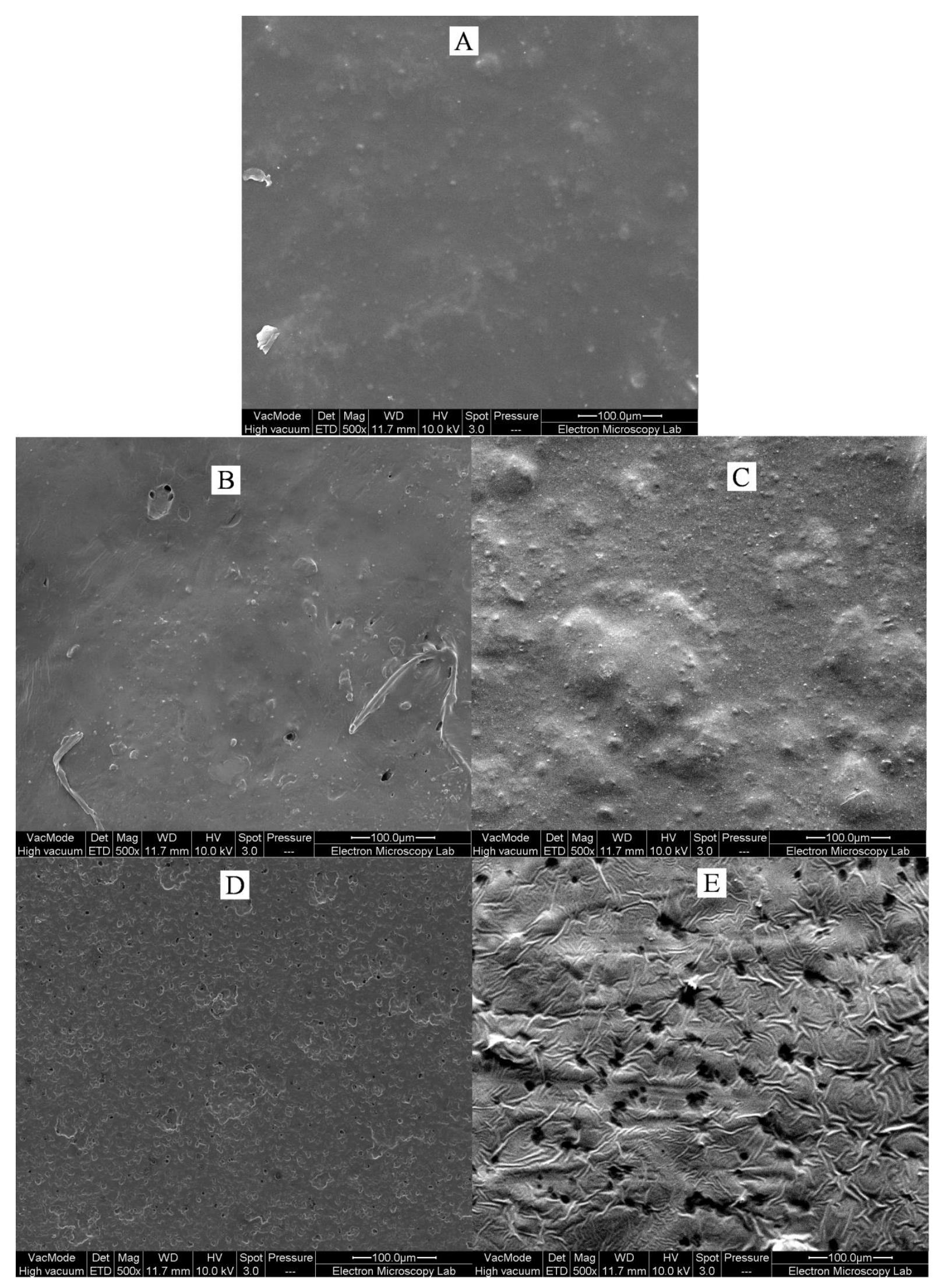

Fig. 2 


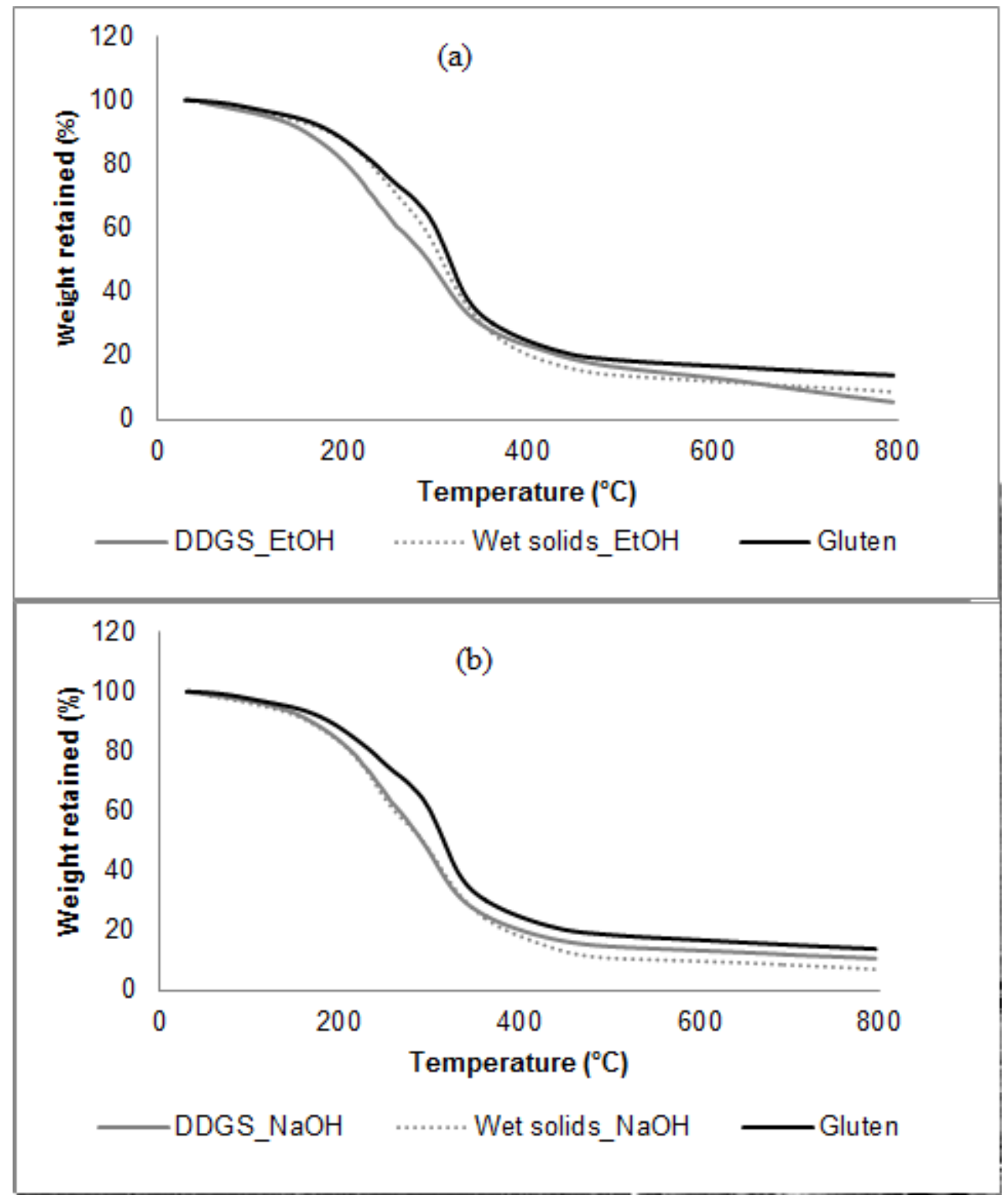

Fig. 3 


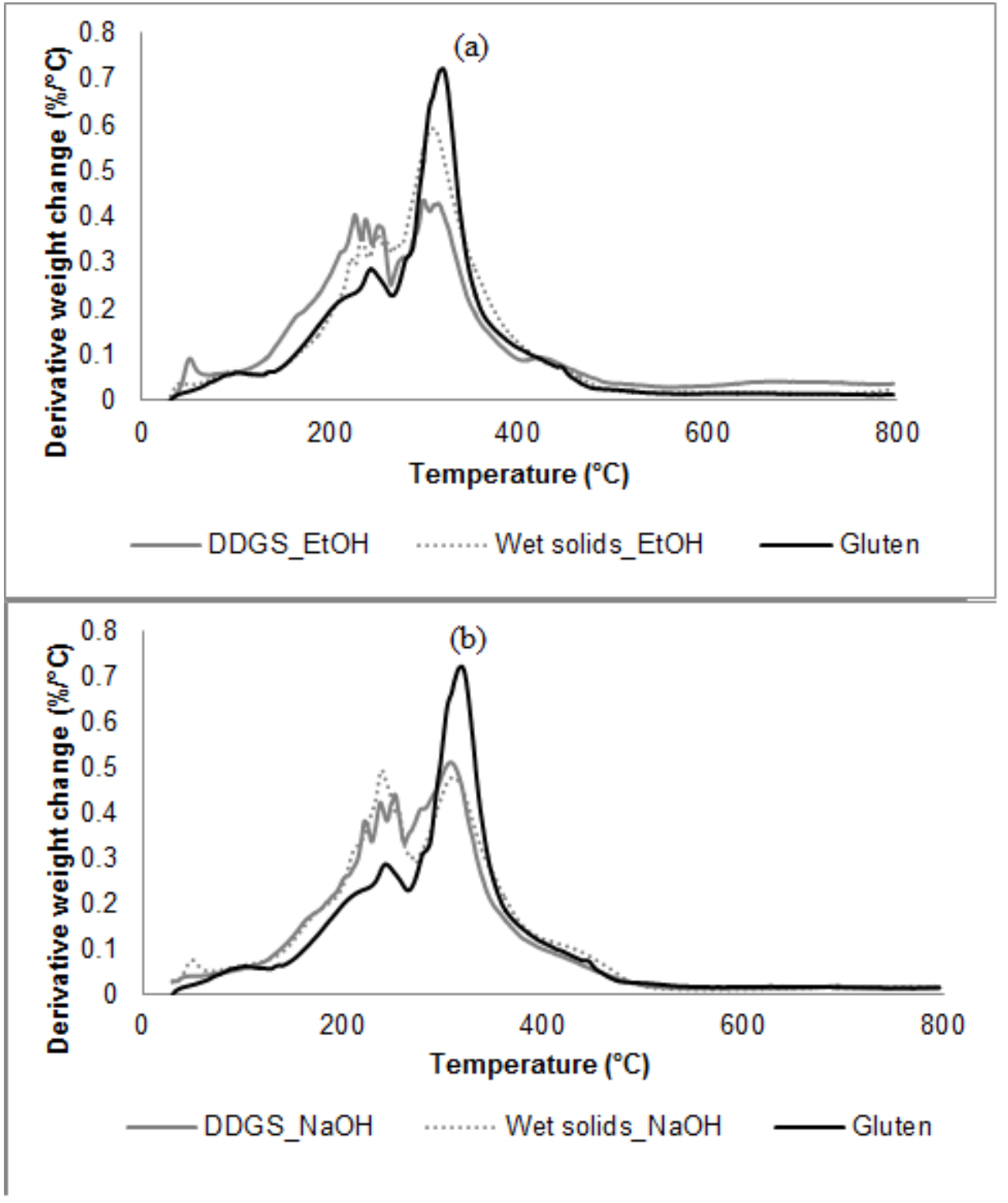

Fig. 4 


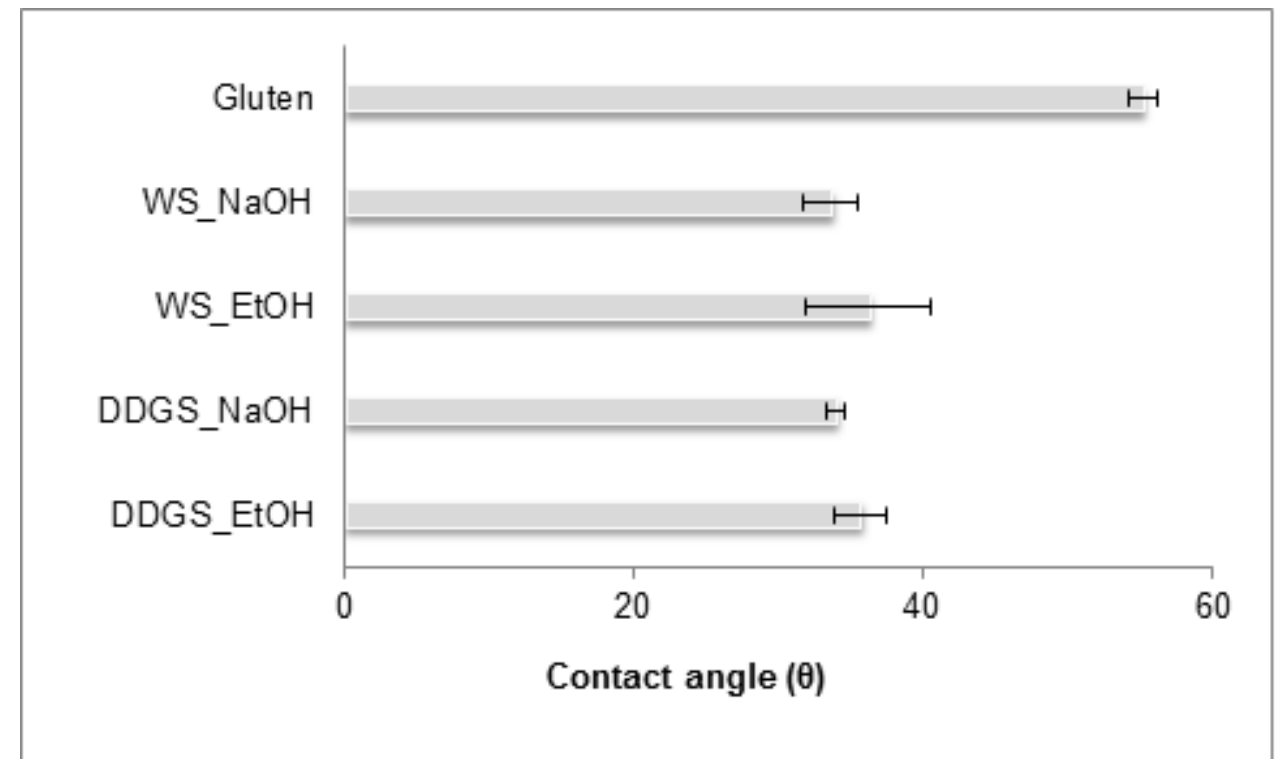

Fig. 5 


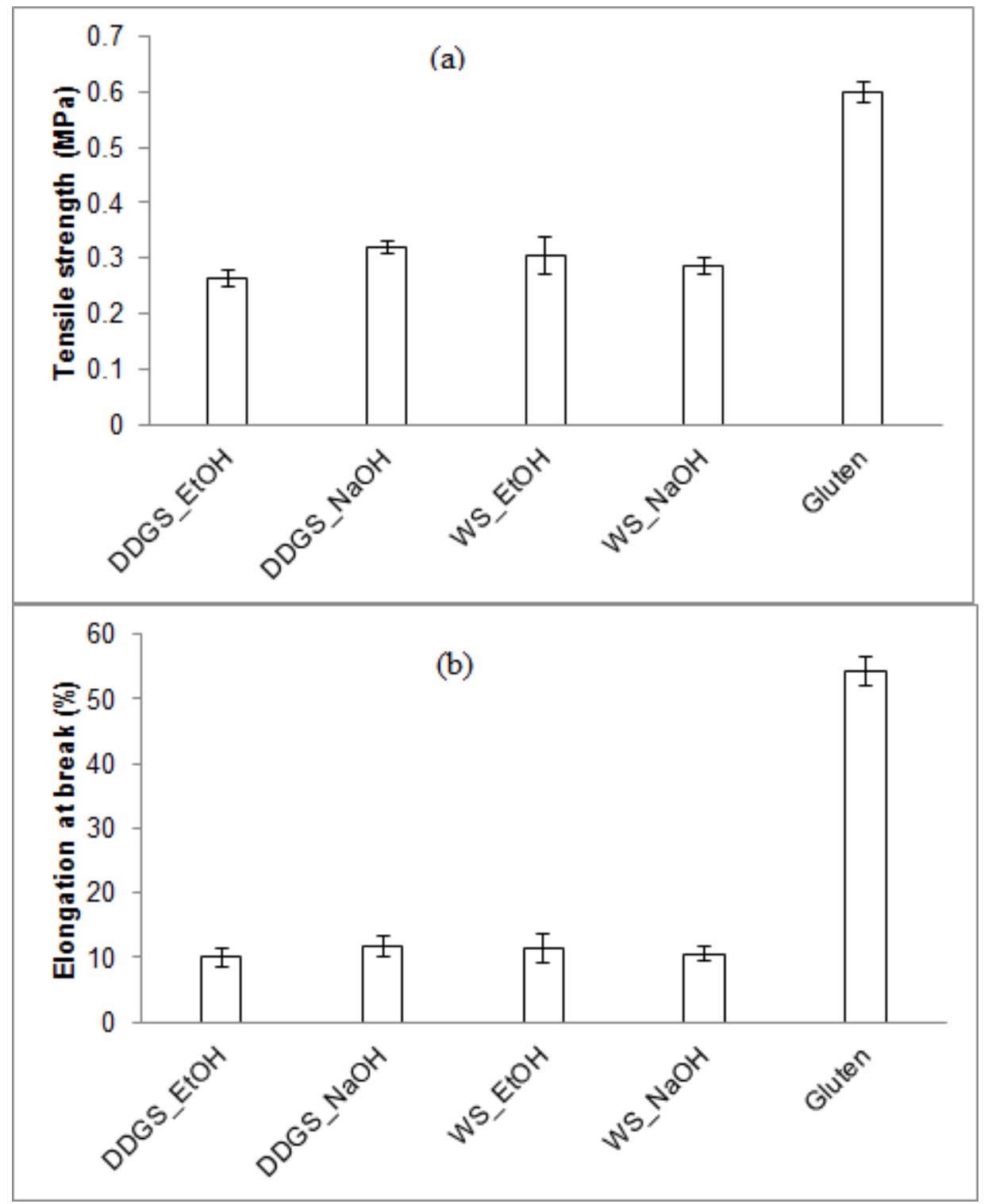

Fig. 6 